http://www.nauka-a-religia.uz.zgora.pl/images/FAG/2005-2006.t.2-3/art.04.pdf

Józef Zon

\title{
Nic nowego w starym sporze ${ }^{*}$
}

Wypowiedź Arcybiskupa Wiednia o obrońcach dogmatu neodarwinowskiego odnosi się do światopoglądowego i filozoficznego kontekstu współczesnego ewolucjonizmu w postaci najbardziej rozpowszechnionej i wśród biologów-ewolucjonistów uznawanej za najmniej kontrowersyjną, za najlepiej uzasadnioną danymi m.in. genetyki osobniczej oraz populacyjnej, ekologii i paleontologii. Wspomniany kontekst stanowi materialistyczny monizm, w obrębie którego uznaje się, iż wszelkie postacie życia oraz człowiek pojawiły się jako rezultat ewolucji materii, która jest jedyną rzeczywistością, manifestującą się w rozmaitych postaciach. W ewolucjonizmie darwinowskim przyjmuje się, że czynnikami powodującymi przemiany Wszechświata (w tym pojawianie się rozmaitych nowych układów i powiązań między mini) są zachodzące przypadkowe zmiany tych układów i zależności między nimi oraz dobór naturalny.

\section{Zagadnienie światopoglądowe: stworzenie czy ewolucja mate- rii}

To fundamentalne przeświadczenie i zarazem wynikająca $\mathrm{z}$ niego dyrektywa postępowania poznawczego każe odrzucać twierdzenia o celowości, realizującej się nie tylko w przyrodzie żywej, ale przede

\footnotetext{
* Recenzent: Robert Росzовuт, Instytut Socjologii Uniwersytetu w Białymstoku.
} 
wszystkim celowości, która odnosiłaby się do Wszechświata jako całości. Wyjaśnianie celowościowe uznaje się za zupełnie bezwartościowe. $\mathrm{W}$ jego miejsce proponuje się stosowanie wyjaśniania przy wykorzystaniu praw ujmujących przebieg procesów tak, jakby przebiegały one celowościowo (teleonomia).

Deprecjonuje się więc wyjaśnianie teleologiczne głównie $\mathrm{z}$ tego względu, że znajduje ono bezpośredni odpowiednik w teologii naturalnej, którą - zwłaszcza biolodzy i filozofowie przyrody zajmujący się przekształceniami świata żywego - uznają za relikt przeszłości. Do tego typu teologii, zdaniem tych badaczy i myślicieli, prowadzi teleologia. Dokładniej mówiąc, chodzi o zaprojektowanie przez Stwórcę postaci Wszechświata, istot żywych, a przede wszystkim człowieka. Tak więc spór nie mieści się w obrębie biologii czy nawet kosmologii, lecz w dziedzinie światopoglądu, którego strukturę szkieletową wyznaczają przekonania i rozstrzygnięcia filozoficzne (przy niektórych typach filozofii ściśle korespondują one $\mathrm{z}$ teologią). Istnieje więc konflikt fundamentalnych nastawień. Mogą one wpływać na postać uprawianej nauki (w tym wypadku o czasowej i przestrzennej zmienności form życia); mogą one także z niej czerpać dane służące za uzasadnienie swoich tez.

Są więc dwa skrajne stanowiska światopoglądowe: ewolucjonistyczne i materialistyczne zarazem oraz kreacjonistyczne i teistyczne, nazywane teizmem kreacjonistycznym. Pomijam tu teizm uznający stałość stworzonej struktury przyrody, stanowisko będące obecnie „skamieniałością fillogenezy idei”. Pomiędzy nimi znajduje się wiele stanowisk pośrednich. Szczególnie interesujące dla mnie jest stanowisko godzące wiedzę o ewolucyjnej zmienności i ewolucyjnym mechanizmie wnoszenia nowości do Wszechświata w określonych fazach jego istnienia z przekonaniem o istnieniu Stwórcy, jego czynną obecnością we Wszechświecie, a szczególnie w życiu poszczególnych ludzi.

Kardynał Wiednia twierdzi, że ani papież Jan Paweł II, ani też wcześniejsze nauczanie Kościoła Katolickiego nie daje podstawy do 
podważania przekonania o celowości przyrody. Wręcz przeciwnie: jest wyrazem przekonania, iż bieg spraw Wszechświata nie jest oddany grze przypadku, lecz jest przewidziany w projekcie, którego autorem jest Stwórca.

\section{Albo ewolucja, albo stworzenie! Czyżby?}

Nie ja pierwszy stawiam pytanie: czy rzeczywiście nie ma obszaru pośredniego pomiędzy tak zdecydowanie spolaryzowanymi postawami? Czy można zajmować wspomniane stanowisko pośrednie, dające szansę pogodzenia najcenniejszych składników stanowisk obydwu postaw? (Za nieziszczalne uważam przy tym oczekiwanie, że się uniknie ataków, czy też zarzutów niekonsekwencji, kierowanych z obydwu stron sporu).

Myślę zatem, że jest warte zachodu podejmowanie prób możliwie rzetelnego traktowania racji rozumu (nauka plus jej składnik, jakim jest ewolucjonizm) i wiary (religia chrześcijańska i zawarty w Piśmie Św. i tradycji Kościoła przekaz o wszechobecności i czynnej roli Boga, szczególnej pozycji każdego człowieka we Wszechświecie). Co więcej, jestem skłonny uznać, iż warto podejmować takie próby (nawet pomimo ryzyka, iż może okazać się, że wysiłki te zostawią ślad jedynie w obszernym rejestrze przedsięwzięć daremnych, choć podejmowanych w dobrych zamiarach).

W naszych czasach nie można już ignorować rzetelnie ugruntowanej wiedzy o zmienności składników Wszechświata zarówno, co do przyrostu ich zróżnicowania, ich liczby czy też sposobów wzajemnego powiązania. Sposób ich opisu, jaki przedstawiają koncepcje ewolucyjne (pośród których szczególną rolę odgrywa obecnie neodarwinizm), pozwala na zmieszczenie ich wszystkich w ramach jednego dynamicznego schematu. Ten schemat jest niezwykle cennym składnikiem obecnej naszej wiedzy o Wszechświecie. Odrzucenie go spowodowałoby istotne jej zubożenie. 
Jednak bezkrytyczne przyjęcie jakiegoś światopoglądu, którego jedną część stanowiłby ewolucjonizm w interpretacji darwinowskiej, a drugą - teza o selekcji naturalnej, oddziałującej na „przypadkową zmienność" jako istotnym składniku mechanizmu przemian, stwarza zagrożenie wykorzystania i nadużycia go w ideologii. Historia tzw. darwinizmu społecznego, który stał się składnikiem narodowego socjalizmu niemieckiego, jest najbardziej jaskrawą ilustracją takiego nadużycia. Do tego bowiem prowadzi zasada traktowania poszczególnych ludzi oraz ich grup jak każdego innego rodzaju istot żywych, które są zróżnicowane, powstały dzięki przypadkowej zmienności, a przy tym podlegały, podlegają i powinny podlegać (to już ideologia!) selekcji. Na marginesie chciałbym zauważyć, że do dziś nauki przyrodnicze są zupełnie bezradne, jeśli by od nich samych oczekiwać odpowiedzi na to, dlaczego wszyscy ludzie mają być sobie równi pod względem praw (co głosi Karta Praw Człowieka), jakie im się przyznaje $\mathrm{z}$ racji samego tylko pochodzenia od rodziców-ludzi. Mogą one za to dostarczyć mnogich argumentów za zróżnicowaniem pomiędzy poszczególnymi ludźmi i grupami ludzi, dając tym samym ,argumentacyjną pożywkę" dla poglądów oraz ideologii selekcjonistycznych i rasistowskich. Z drugiej strony literalne odczytywanie Księgi Rodzaju $\mathrm{w}$ odniesieniu do rzetelnie nabytej wiedzy z zakresu przyrodoznawstwa jest błędem. Ten literalizm przeniesiony w obszar światopoglądu i ideologii z całą pewnością może hamować postęp wiedzy przyrodniczej.

Trzeba więc uznać, że każdy indywidualny człowiek, i struktury społeczne, jakie on tworzy, jest czymś więcej niż organizmem żywym. Jego „wymiarowość” jest bogatsza, tak jak wymiarowość sześcianu jest bogatsza od wymiarowości prostokątów, trójkątów i punktów powstających na różnych jego przekrojach. Uwidocznienie tej dodatkowej wymiarowości staje się możliwe właśnie dzięki tzw. naukom społecznym, filozofii, teologii i sztuce. Wszystkie one spotykają się w dziedzinie światopoglądu. 


\section{A może da się pogodzić ideę Boga-projektanta, zatroskanego swym dziełem, z tezą 0 ewolucji?}

W Księdze Rodzaju jest sformułowanie, które - moim zdaniem można rozumieć $\mathrm{w}$ podany $\mathrm{w}$ śródtytule sposób. W odniesieniu bowiem do większości faz stwarzania Bóg uznaje, że to, co stworzył, jest dobre, a szóstego dnia uznaje nawet, że całe dokonane dzieło stwarzania jest „bardzo dobre” (Rdz 1). Czy takie stwierdzenie autora Księgi Rodzaju nie można uznać za świadczące o tym, iż Bóg zachowuje się jak projektant i wykonawca zarazem: poddaje ocenie to, co powstawało dzięki urzeczywistnieniu Jego zamiaru. Być może da się to nawet pogodzić z ideą selekcji - to, co „nie było dobre” nie pozostaje składnikiem dzieła stwarzania?

Oczywiście, w związku z taką interpretacją można postawić pytanie: czy to, co zostało uznane za dobre, było wszystkim, co w ogóle zaistniało na określonym etapie stwarzania, czy tylko pewną częścią bogatszego zestawu? Twierdząca odpowiedź na pierwszą część pytania pokrywa się z tradycyjnym poglądem, że wszystko, co wtedy ,wyszło z ręki Boga", było stworzone bezpośrednio i w postaci doskonałej, w istocie już niezmiennej. Skłonienie się ku drugiej możliwości daje szansę interpretacji ewolucyjnej i teistycznej zarazem. Trudność jednak stanowi implikowana teza o tym, że Bóg powoduje powstawanie tworów nieudanych, które sam ocenia, że „nie są dobre”.

Spodziewam się też, że natychmiast zostanie podniesiony argument, iż zachodzi istotna różnica pomiędzy tym, co powstaje jako rezultat świadomego działania projektanta i jednocześnie sprawcy, a czym innym wybranie tylko ze zbioru różnych jednostek tych, które są najbardziej odpowiednie (albo, dokładniej mówiąc, wyeliminowanie lub dopuszczenie do wyeliminowania mniej odpowiednich). Sądzę, że taka hipoteza stwarza bliższą korespondencję pomiędzy tym treściowym składnikiem Księgi Rodzaju a współczesną filozofią przyrody, uwzględniającą dynamikę wszechświata, na którą nie mogą za- 
mykać oczu przedstawiciele wielu dziedzin przyrodoznawstwa. Choć dosłownie rozumiany przekaz o tym, że człowiek został ulepiony przez Boga $\mathrm{z}$ prochu ziemi i że Bóg tchnął w jego nozdrza tchnienie życia ( $\mathrm{Rdz} 2,7)$, doskonale przystaje do obrazu Projektanta-Wykonawcy pierwszego człowieka, to bardzo daleko znajduje się od tego, co jako wiarygodny opis tego historycznego wydarzenia może zaakceptować współczesny przyrodnik. W odniesieniu do takiego dosłownego rozumienia opisu wydarzeń „,na początku” Kościół Katolicki zalecał ostrożność już w końcu XIX w. (encyklika Providentissimus Deus - 1892). W połowie ub. stulecia ten ogólny problem został podjęty w encyklice Humani generis (1950) w odniesieniu do powstania człowieka jako gatunku i człowieka jako konkretnej osoby. Pierwszy z tych dokumentów - korzystając z rady św. Augustyna - zobowiązuje teologów do obstawania przy prawdzie Pisma św. Jednak w sytuacji wyglądającej na konflikt rzetelnie uzasadnionej prawdy rozumu i prawdy wiary zaleca ten Myśliciel najpierw podjęcie próby wykazania, że twierdzenia uczonych $\mathrm{w}$ istocie nie podważają prawdy zawartej w Piśmie. Jeśli to się nie powiedzie, powinni wykazać błędność tych poglądów albo też pozostać przy prawdzie zawartej w Piśmie Św.

W drugim ze wspominanych dokumentów Papież w dalszym ciągu zachęca do krytycznego dialogu pomiędzy teologami a przyrodnikami, podtrzymując wcześniejsze stanowisko Kościoła w odniesieniu do preferencji prawdy Pisma Św. w stosunku do prawd przyrodoznawstwa, które wyglądają na sprzeczne $\mathrm{z}$ nim. Taki dialog podejmowali w swoich pracach m.in. księża profesorowie Kazimierz Kłósak, Tadeusz Wojciechowski oraz Kazimierz Kloskowski, a obecnie kontynuują Michał Heller i abp. Józef Życiński. Sytuacja po 1950 r. zmieniła się więc na tyle, że nie można się dziwić, iż Jan Paweł II w liście do Papieskiej Akademii Nauk (1996) użył sformułowania ,teoria ewolucji jest więcej niż hipotezą". Jednym z ogólnych pytań, organizujących ten dialog, jest pytanie o możliwość pogodzenia teologicznej tezy o czynnym udziale Boga w historii Wszechświata z przyrodniczą (a także filozoficzną) tezą o zachodzeniu i roli w niej procesów ewolu- 
cyjnych. Sloganowe uproszczenie tego problemu zawiera się w pytaniu: „przypadek czy celowość”.

Warto w związku z tym zauważyć, że nie jest poprawne uznawanie za rozłączne względem siebie przypadkowości i celowości. Moga bowiem zachodzić procesy zmierzające do określonego stabilnego stanu (który można uznać za cel), nawet pomimo wpływu na te procesy zdarzeń przypadkowych. Można też zaprojektować cały układ w ten sposób, żeby dzięki akumulacji skutków zdarzeń zupełnie przypadkowych, w określonym czasie $\mathrm{z}$ wysokim prawdopodobieństwem, będzie wytwarzany określony produkt czy pożądany stan układu. Prostym przykładem takiej sytuacji może być projekt prostego reaktora chemicznego, w którym część cząsteczek odpowiednio dobranych reagentów, wskutek zupełnie chaotycznych zderzeń, zmienia się w inne cząsteczki. Te z kolei mogą przyspieszać zachodzenie przekształceń, dzięki którym one same powstały. Jak długo procesy zachodzą zgodnie z zamiarem projektanta układu, może on, ale nie musi, ingerować $\mathrm{w}$ bieg procesów w reaktorze. Jeśli jednak uzna za właściwe, może poprzez np. zmianę temperatury spowodować zmiany tempa, a nawet jakości procesu. Ten sam skutek może uzyskać poprzez odprowadzanie (eliminowanie) z reaktora molekuł niepożądanego rodzaju. Tak więc typów zaprojektowania może być wiele, poczynając od urzeczywistnienia pomysłu prostej dźwigni, kończąc na pomysłach procesów i struktur skrajnie wyrafinowanych. Wśród tych ostatnich mogą być takie, których niektóre składniki zostały zaprojektowane dzięki wdrożonej zasadzie. Bóg-stwórca w takim ujęciu mógłby być uznany nie tyle za projektanta i wykonawcę każdego pojawiającego się układu we Wszechświecie, ale projektantem procesu przemian Wszechświata, ingerującym w przebieg niektórych faz procesu przekształceń. Wygląda raczej na to, że Bóg posłużył się wyrafinowaną zasadą projektowania, która nie wykluczałaby roli zdarzeń przypadkowych. Wypowiedź A. Einsteina, że „Bóg nie jest złośliwy, lecz wyrafinowany" korespondowałaby z taką propozycją.

To, co jest jego dziełem, to projekt mechanizmu, który nie wyklucza roli zdarzeń i stanów niezwykle wrażliwych na zaburzenia. 
Wolna wola człowieka, „włączona w projekt stworzonego Wszechświata, wymagałaby przecież takich subtelnych uzależnień. Dzięki nim właśnie możliwe są niezwykle skomplikowane jej uzależnienia od stanów wewnętrznego i zewnętrznego środowiska, dzięki nim Bóg, poprzez np. wyproszone w modlitwie „muśnięcia” ośrodka decyzyjnego jakiegoś człowieka, może pomagać w podejmowaniu decyzji, których skutki czasami mogą dotyczyć losów milionów innych ludzi.

Satysfakcjonująca wydaje mi się wizja stworzonego wszechświata dynamicznego, o trudnym (albo nawet niemożliwym) do przewidzenia biegu procesów najbardziej elementarnych, ale przy tym ostatecznie jednoznacznej trajektorii procesu globalnego, którego one same są składnikami. W założeniach konstrukcyjnych takiego świata musiały się znaleźć ciągi procesów, które doprowadziły do pojawienia się istot o ciele bardzo zbliżonym do ciała obecnego człowieka. Ciało to zostało po raz pierwszy ubogacone w zasadę (czynnik), dzięki któremu czuje się on tworem odrębnym od wszystkiego innego, wartościowym i zobowiązanym do szanowania wartości; istotą odpowiedzialną i oczekującą odpowiedzialności od istot do sobie podobnych. Warto zauważyć, że Kościół Katolicki, papieskim orzeczeniem zawartym w Humani generis (1950), nie uznaje za niewłaściwe dyskutowanie o ewolucyjnym pochodzeniu ciała pierwszych ludzi, jakkolwiek przestrzega przed pochopnością wydawania sądów w tej sprawie, ponadto rezerwuje dla każdej jednostki ludzkiej pozycję wyróżnioną w całej przyrodzie.

Podsumowując: to, co przypadkowe w jednostkowych realizacjach, nie musi wykluczać uporządkowanego biegu procesu, nawet z góry zaprojektowanego, którego to jednostkowe zdarzenie jest składnikiem. Przypadek i projekt globalnego procesu nie wykluczają się tak, jak przypadek i konieczność w opinii adherentów ewolucjonizmu materialistycznego. Można więc bez ryzyka poniesienia uszczerbku na opinii bycia osobą krytyczną, ceniącą osiągnięcia przyrodoznawstwa, być mimo to zwolennikiem poglądu o Projekcie Największym z Możliwych, poglądu, który jest składnikiem m. in. wiary chrześcijan. 
Nie zachodziłaby więc sprzeczność pomiędzy tym, co osiągamy dzięki danemu nam rozumowi i zadanemu nam obowiązkowi dobrego nim posługiwania się, a tym, co jest przekazem i wymaganiem wiary religijnej; tym, co Kościół Katolicki od dawna głosi, czego w istocie rzeczy broni kardynał Schönborn i co Jan Paweł II już w pierwszym zdaniu encykliki „Fides et Ratio” (1998) opisuje posługując się metaforą dwu skrzydeł. 